\title{
BREEDING OF THE SHORT-EARED OWL IN NEW MEXICO
}

\author{
RAYMOND A. MEYER, 3065 Camino Real, Las Cruces, New Mexico 88001; \\ ltecnm@gmail.com
}

DEEANNE T. MELIOPOULOS, 2241 Entrada del Sol, Apt. 6A, Las Cruces, New Mexico 88001; deeannem@nmsu.edu

GRANT M. BEAUPREZ, New Mexico Department of Game and Fish, 202 CR 3, Texico, New Mexico, 88135; grant.beauprez@state.nm.us

SARTOR O. WILLIAMS III, Division of Birds, Museum of Southwestern Biology, University of New Mexico, Albuquerque, New Mexico 87131; sunbittern@earthlink.net

\begin{abstract}
We report four instances of breeding by the Short-eared Owl (Asio flammeus) in three areas of New Mexico in 2014, the first confirmed breeding for the state and southernmost known for interior North America. A nest and two prefledged juveniles plus a family group were at two sites in Otero County, a pair with one pre-fledged juvenile was found in Luna County, and a family group was observed in Roosevelt County. Each area had received substantial precipitation in September 2013, resulting in increased vegetative cover and growth of annual plants, presumably increasing small mammal prey for owls. Regurgitated pellets collected from the Otero County sites revealed that the Short-eared Owls preyed mainly on heteromyid rodents. Breeding should be considered possible for birds detected in March and later in areas south of the normal range when conditions are favorable.
\end{abstract}

In North America, the Short-eared Owl (Asio flammeus) breeds across the continent from the low Arctic, including southern Alaska, south to roughly $40^{\circ}$ north latitude in the western states of Nevada, Utah, Colorado, and Kansas (AOU 1998, Wiggins et al. 2006). Historically, it nested in suitable habitat along the entire California coast, but in recent years it has bred consistently only in the central and northern regions of the state (Grinnell and Miller 1944, Garrett and Dunn 1981, Wiggins et al. 2006, Roberson 2008). On the east coast, the Short-eared Owl breeds from the northern portions of the Canadian provinces south to northern Virginia (AOU 1998). In interior states, instances of Short-eared Owls nesting south of the species' usual limit have been reported in southern Colorado (Boyle 1998), northern Oklahoma (Nice 1931, Blaha et al. 1995, Wilson 1995), and Kentucky (Stamm and Clay 1989).

The Short-eared Owl is a partial migrant, withdrawing from the northern portion of its range to winter farther south. It winters from southernmost Canada south through the U.S. into northern Mexico, and less commonly as far south as Oaxaca and the Yucatan Peninsula in southern Mexico (EnriquezRocha et al. 1993, Howell and Webb 1995, AOU 1998). The Short-eared Owl moves nomadically, responding to fluctuations in its prey such that its distribution and abundance can vary greatly from season to season anywhere in its range, including occasional extralimital breeding (Clark 1975, Poulin et al. 2001, Wiggins 2004, Wiggins et al. 2006, Booms et al. 2014). 


\section{STATUS IN NEW MEXICO}

In New Mexico, the Short-eared Owl is considered an uncommon migrant and winter resident statewide with numbers and distribution varying from year to year (Hubbard 1978, Avery and Keller 2010). It is usually associated with open habitats, particularly open grasslands and wetlands, but it also occurs in shrublands and stands of trees (Ligon 1961, Wiggins 2004, Avery and Keller 2010). In the southern part of the state from November to March, Short-eared Owls use lowland desert swales and basins vegetated primarily with dense grasses including Tobosa (Pleuraphis mutica) and Alkali Sacaton (Sporobolus airoides) (Meyer pers. obs.).

Despite circumstantial evidence, Short-eared Owl breeding has not been confirmed previously in New Mexico. Such evidence was first reported from eastern New Mexico in 2005 (Avery and Keller 2006; Figure 1), on the basis of a suspected pair noted by multiple observers $14.5 \mathrm{~km}$ west of Portales in northern Roosevelt County from May to August. Though the birds' pro-

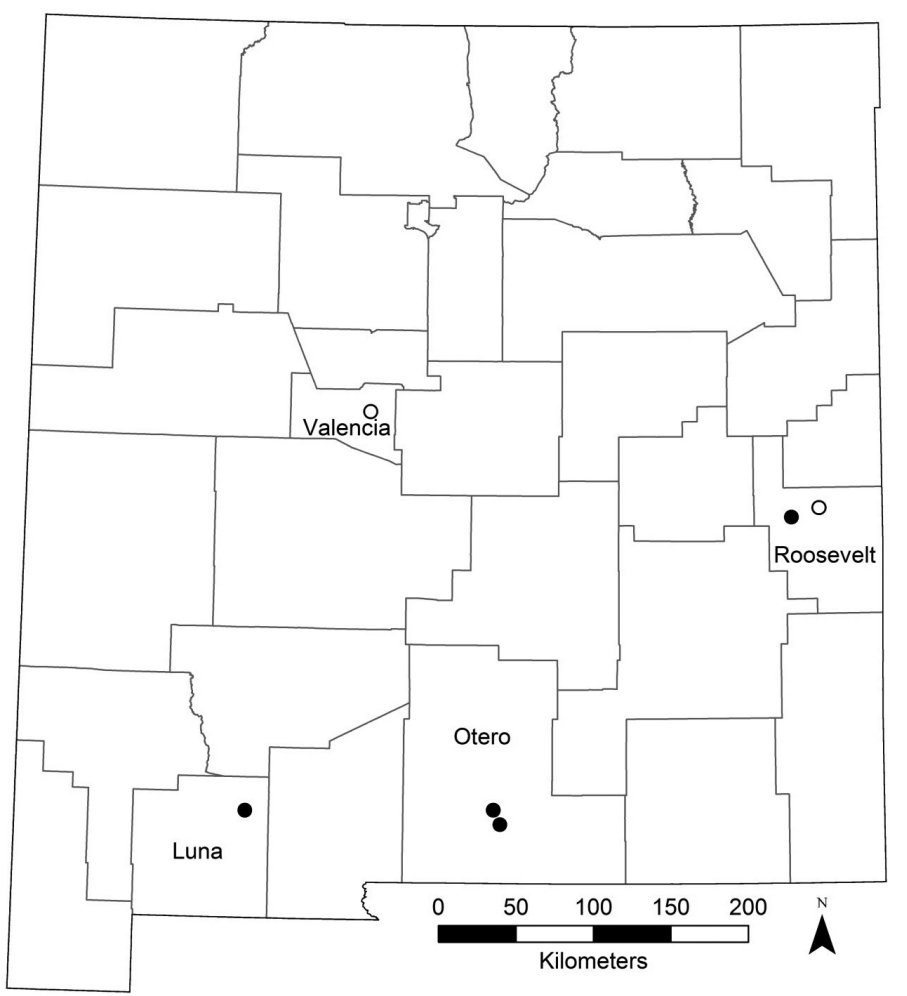

Figure 1. Locations of Short-eared Owl breeding in Roosevelt, Otero, and Luna counties, New Mexico, in 2014 (solid circles) and likely breeding in Roosevelt County in 2005 and Valencia County in 2007 (open circles). 
longed stay in presumably suitable habitat during the breeding season, and their territorial and aggressive behavior, suggested they were breeding, no nest or young were witnessed. A second instance involved up to 12 birds, possibly including a family group, in grasslands of central New Mexico near Tome, Valencia County, from June to July in 2007 (N. Am. Birds 61:621, 2008; Figure 1). In addition, Short-eared Owls were observed with no suggestion of nesting on at least five occasions in summer from 2000 to 2009 in Colfax (N. Am. Birds 59:634, 2006), Harding (N. Am. Birds 55:468, 2001), Curry (N. Am. Birds 54:409,2000; 63:631, 2010), and Hidalgo (N. Am. Birds 61:621, 2008) counties in eastern and southern New Mexico.

\section{Breeding in 2014}

In 2014, breeding by Short-eared Owls was documented in two areas of south-central New Mexico and at another site in eastern New Mexico (Figure 1). On Otero Mesa in central Otero County, Meyer observed two breeding pairs approximately $10 \mathrm{~km}$ apart from late May to early June. At one of the sites, the nest, two young, and two adults were observed. At the second location, two juveniles and two adults were seen but a nest was not found. During the same period, Meliopoulos observed one young bird and two adults farther west near Nutt in northeastern Luna County. In eastern New Mexico, Beauprez saw up to six birds, presumably a family group, southwest of Floyd in northern Roosevelt County from late May to early July.

\section{Otero County: Cocklebur Tank}

On 28 May 2014, Meyer encountered a pair of owls aggressively defending an area on the Otero Mesa portion of the McGregor Range of Fort Bliss. One of the adult owls stooped on him several times, emitting loud alarm calls, while the other bird remained in flight at a distance. A search of the area resulted in the discovery of a nest and, nearby, an owlet approximately 12 days old $\left(32.348^{\circ} \mathrm{N}, 105.711^{\circ} \mathrm{W}\right.$, elevation $\left.1508 \mathrm{~m}\right)$. The McGregor Range includes the northwestern corner of Otero Mesa bounded to the north by the foothills of the Sacramento Mountains and to the west by the Tularosa Basin. In this portion of the range military activity is limited but modest numbers of livestock graze. Roads are mostly unmaintained and used infrequently.

The nest was a simple scrape with minimal lining of plant material and feathers. It was located on the northern perimeter of a small, shallow basin adjacent to the earthen Cocklebur Tank. Surrounding the nest was a dense canopy of vegetation, primarily Russian Thistle (Kali tragus) with some gumweed (Grindelia sp.), remaining from the previous growing season. Grass cover was sparse, primarily Vine Mesquite (Hopia obtusa). The accumulated Russian Thistle formed a ring about $25 \mathrm{~m}$ wide and $0.6 \mathrm{~m}$ high around the northern edge of the basin. Much of the basin's bottom was vegetated with dense cocklebur (Xanthium sp.). Surrounding the basin was homogeneous plains-mesa grassland with widely scattered Soaptree Yuccas (Yucca elata) and shrubs on gently sloped terrain (Mehlhop et al. 1996).

On 3 June, two adults and two young were in a small group of shrubs (Condalia ericoides) about $120 \mathrm{~m}$ northwest of the nest (Figure 2). The 
young birds appeared incapable of flight and presumably had moved from the nest on foot. On 20 June, no Short-eared Owls were detected in the area.

\section{Otero County: Godfrey Tank}

On 22 May 2014, Meyer observed a Short-eared Owl landing at a large mat of Russian Thistle southwest of Godfrey Tank, in a broad, rather flat swale known as El Paso Draw, about $10 \mathrm{~km}$ north-northwest of Cocklebur Tank. He initially presumed the owl to be a late migrant, but after finding the nest at Cocklebur Tank, he revisited Godfrey Tank on 28 May. No owls were detected in the immediate vicinity of the 22 May sighting, but two adults and an apparent juvenile were encountered roughly $650 \mathrm{~m}$ to the north $\left(32.432^{\circ} \mathrm{N}, 105.757^{\circ} \mathrm{W}\right.$, elevation $\left.1469 \mathrm{~m}\right)$, within $100 \mathrm{~m}$ of each other roosting under small Soaptree Yuccas. After being flushed, one adult flew overhead briefly emitting alarm calls, while the other bird flew a short distance to another yucca. In a later visit to the site on 3 June, four birds were observed in close proximity to each other, roosting under yuccas about 165 $\mathrm{m}$ east of the 28 May location. After being flushed, two of the birds flew a few hundred meters to the east while the other two birds, roosting under one yucca, flew a short distance before landing. The behavior, slightly different appearance, and down and feathers found at their roost site suggested that the two latter birds were juveniles.

At this site, the dominant woody vegetation was short (height mostly $<2$ $\mathrm{m})$ Soaptree Yucca and Sand Sagebrush (Artemisia filifolia). Grass cover was sparse, primarily dropseeds (Sporobolus spp.), forbs were numerous, and the soil was sandy. Small clusters of dead Russian Thistle had built up around woody plants and in depressions throughout the area. Roost sites also were found in dense accumulations of Russian Thistle along a nearby fence. Two hours of searching in the roosting area or in the adjacent draw failed to reveal a nest.

Nine pellets collected at the Cocklebur Tank nest, possibly those of nestlings, were uniform in size and contained partial skulls and lower mandibles of 23 pocket mice, likely the Silky Pocket Mouse (Perognathus flavus) on the basis of morphological characteristics, geographic location, and habitat (Clary et al. 1999, Dalquest and Stangl 1986). More than 10 castings collected at the daytime roost near Godfrey Tank were more variable in composition, containing primarily pocket mice (30), but also five kangaroo rats (Dipodomys sp.), two unidentified heteromyids, a gopher (Geomyidae), and an unidentified bird.

\section{Luna County: Nutt Grasslands}

On 1 June 2014, Meliopoulos observed a Short-eared Owl in flight during a breeding bird survey on the Nutt grasslands. Investigation after the bird landed revealed a second adult and one owlet, all roosting under separate Soaptree Yuccas within $15 \mathrm{~m}$ of each other $\left(32.568^{\circ} \mathrm{N}, 107.465^{\circ} \mathrm{W}\right.$, elevation $1435 \mathrm{~m}$; Figure 3). The young owl appeared to be nearly fledged, being fully feathered with a black face, well-developed ear tufts, and an unstreaked 
buffy breast and belly. On 4 June, a search within a radius of $100 \mathrm{~m}$ of the detection site yielded neither the young nor adult owls, only down feathers and two pellets under Soaptree Yuccas within $60 \mathrm{~m}$ of the owlet's location. The Soaptree Yuccas used by the owls ranged from 1 to $1.3 \mathrm{~m}$ in height.

The Nutt grasslands are dominated by Tobosa grass with scattered forbs, Soaptree Yuccas, and Longleaf Ephedra (Ephedra trifurca). The owls were in an area of dense Tobosa and small clusters of widely spaced yuccas with nearby fences lined with dense Russian Thistle. The Nutt grasslands are considered one of the few remaining tracts of relatively intact desert grassland, though a 769-ha wind farm was installed there in 2011, as well as a 202-ha solar facility in 2013. The owls were located $987 \mathrm{~m}$ from the solar facility, $3.43 \mathrm{~km}$ from the nearest wind turbine, and $219 \mathrm{~m}$ from New Mexico Highway 26.

\section{Roosevelt County: Southwest of Floyd}

On 29 May 2014 during the Floyd Breeding Bird Survey, L. F. Neely observed a Short-eared Owl 13.4 km southwest of Floyd in northern Roosevelt County. During a visit to the same area on 14 June, Beauprez did not see owls at the original detection site but flushed three, suspected to be two adults and a fledgling, while driving approximately $560 \mathrm{~m}$ to the north $\left(32.412^{\circ} \mathrm{N}, 103.684^{\circ} \mathrm{W}\right.$, elevation $\left.1338 \mathrm{~m}\right)$. The owls flushed from the roadside where dense Russian Thistle had accumulated along a fence line. On 26 June Beuaprez observed six owls along the same road about $120 \mathrm{~m}$ south of the 14 June location. In a final visit to the site on 8 July he flushed four Short-eared Owls. Roosevelt County lies at the western edge of the shortgrass steppe region of the Great Plains. The vegetation at the site was primarily native short/mixed grassland, minimally disturbed, dominated by grama (Bouteloua spp.), with widely scattered Sand Sagebrush.

No direct evidence of Short-eared Owl nesting was observed at the Floyd site, but the photographs of four individuals taken on 14 June suggested that two, if not all, were juveniles (D. Wiggins, D. Holt, pers. comm.). Two showed the dark facial disks typical of young birds. The plumage of all four was richly colored and unworn, suggesting that all were hatch-year birds. In addition, it is unlikely that more than two adults would occur during the breeding season in such close proximity or that adults would be attending young as late as July.

\section{Chronology}

Short-eared Owls begin breeding in February, and most nest from April to mid June (Wiggins et al. 2006). At the New Mexico sites, the early stages of breeding, including pair establishment, probably occurred in March. For nests on Otero Mesa and the Nutt grasslands, we estimate the clutches were completed between 25 March and 18 April, hatching from 24 April to 16 May, and fledging from 25 May to 16 June, on the basis of known intervals for stages of the nest cycle (Wiggins et al. 2006). 


\section{DISCUSSION}

The Short-eared Owl observations in 2014 represent the first confirmed breeding for this species in New Mexico and the most southerly documented for interior North America, approximately $300-500 \mathrm{~km}$ beyond the southernmost known interior breeding sites in northern Oklahoma and southern Colorado. Nevertheless, the Short-eared Owl may breed widely, albeit infrequently, south of its normal range. Given previous reports of suspected breeding and periodically favorable conditions, it likely did so in New Mexico prior to 2014 (see Avery and Keller 2006, 2010). For example, a widespread rodent irruption, the result of a wet monsoon season in 2006, prompted unusual nesting in 2007 by raptors including the Long-eared Owl (Asio otus) and Northern Harrier (Circus cyaneus) at multiple lowland locations across the state (N. Am. Birds 61:489, 2007; 61:621, 2008). The winter-spring season of 2007 produced an unprecedented number of Short-eared Owl sightings in New Mexico (Williams unpubl. data) and the apparent family group in Valencia County. Occasional summer sightings also have been reported from coastal and inland Texas where breeding was not suspected but possible (N. Am. Birds 57:516, 2004; 59:622, 2006), including sites south of the New Mexico breeding localities (M. W. Lockwood pers. comm.).

The locations of New Mexico breeding in 2014, spanning a distance of $390 \mathrm{~km}$ and two ecoregions, shared common habitat features. All areas consisted of relatively flat, extensive grasslands, open or with sparse shrubs, although the cover and composition of grass varied. Apart from infrequent traffic on roads, there was little human activity near the sites. Dense accumulations of Russian Thistle, used in concealment at the Cocklebur Tank nest, also was potential nesting habitat at the other three sites. Use of such thickets was more likely at the Godfrey Tank and the Floyd sites where other habitat suitable for nesting was limited. Tall, dense tobosa grassland, similar in structure to nesting habitat farther north, was a viable option in Luna County. In addition to cover, Russian Thistle provides a food source for rodent prey (Forbes 1962, Schmidly 2004, Longland 2007).

Breeding of the Short-eared Owl has been closely linked to the abundance of small mammals (Bent 1938, Pitelka et al. 1955, Clark 1975). In arid regions, the growth of vegetation, particularly annual plants, induced by rain stimulates rodents' reproduction and rapid population growth (Brown and Heske 1990, Ernest et al. 2000, Lightfoot et al. 2012). The areas where the Short-eared Owls nested received rainfall well above average late in the 2013 growing season, following a period of severe drought. In September 2013, $12.6 \mathrm{~cm}$ fell at the Remote Automated Weather Station on Otero Mesa; 7.6-17.6 cm fell at stations around Nutt, and $15.1 \mathrm{~cm}$ was recorded at the Melrose Range station northwest of Floyd (www.wrcc.dri.edu/raws.dri.edu/index.html).

Breeding Short-eared Owls prey primarily on small mammals, particularly voles (Wiggins et al. 2006, Booms et al. 2014). South of the breeding range, wintering Short-eared Owls rely on other prey, and their diet may be more varied (Valdez-Gómez et al. 2009, Williford et al. 2011). The pellets collected on Otero Mesa in 2014 suggested that the owls preyed heavily on small heteromyids. Pocket mice (Chaetodipus spp., Perognathus spp.) and Ord's Kangaroo Rat (Dipodomys ordii) have high reproductive rates and 


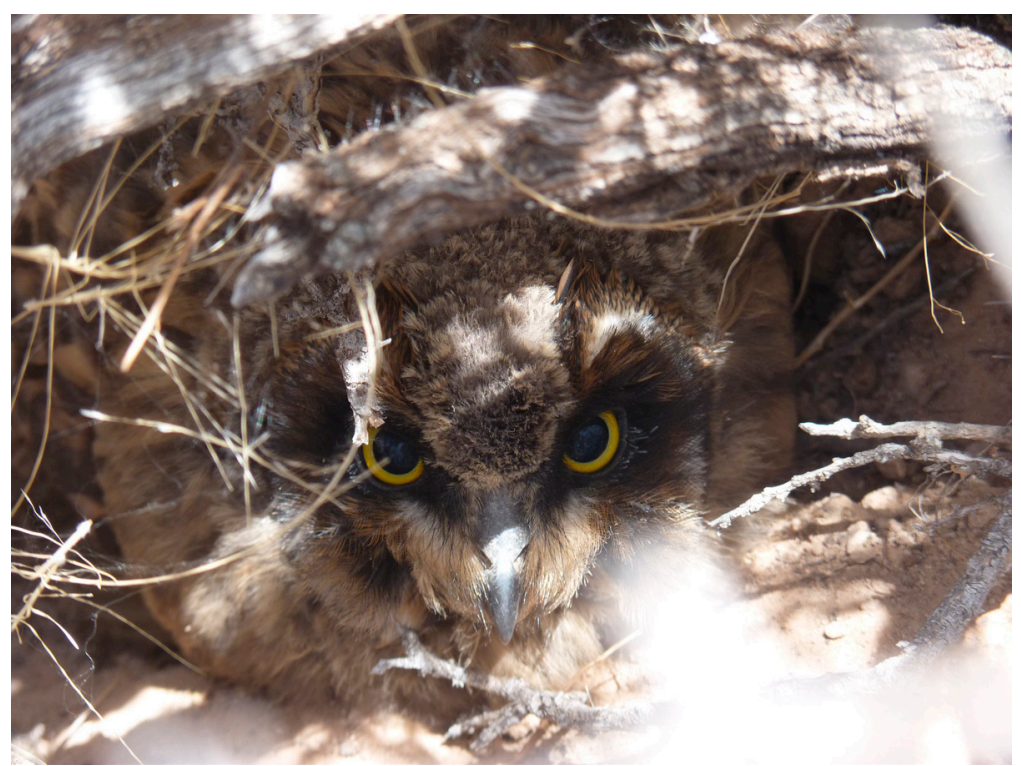

Figure 2. One of two pre-fledged Short-eared Owls roosting under a shrub (Condalia ericoides) about 120 m from the nest on Otero Mesa, Otero County, New Mexico, 3 June 2014.

Photo by Raymond A. Meyer

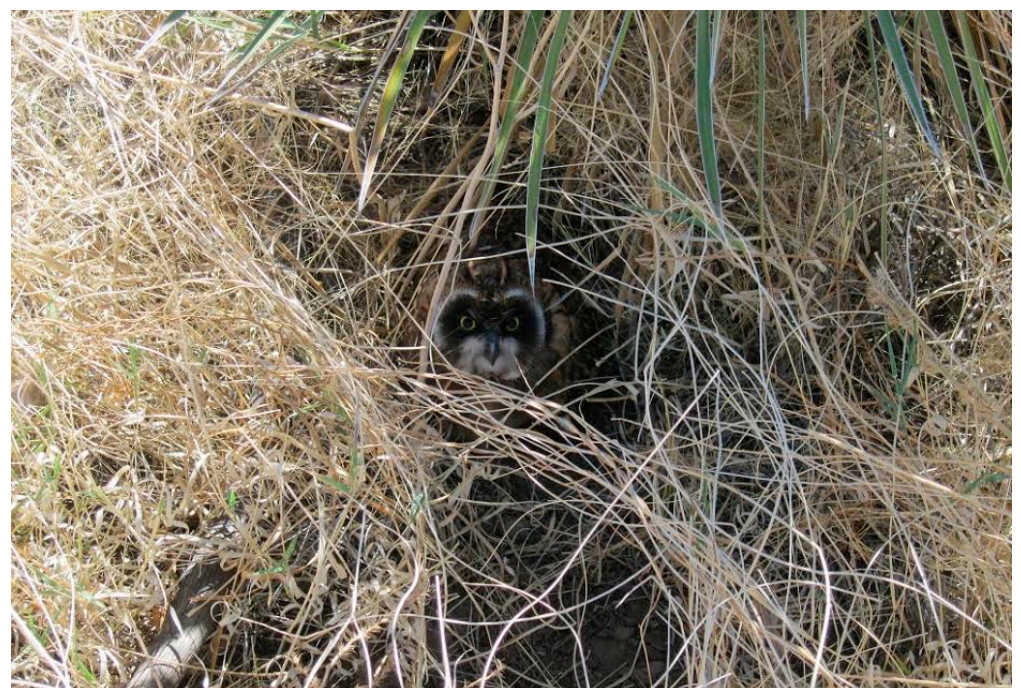

Figure 3. Pre-fledged Short-eared Owl in tobosa grassland west of Nutt, Luna County, New Mexico, 1 June 2014. 
are active year round (Brown and Zeng 1989, Thibault and Brown 2008, Lightfoot et al. 2012). At Fort Bliss, Clary et al. (1999) found the Silky Pocket Mouse (Perognathus flavus) was the most abundant rodent and the one most frequently captured in yucca grassland and open grama grassland. While increased numbers of rodents likely contributed to the Short-eared Owl breeding on Otero Mesa, the low total biomass of the small-mammal community dominated by diminutive pocket mice (weight 6-10 g) may have resulted in owl broods smaller than in areas with larger, more typical prey, where clutch sizes are as high as 11 (Clark 1975, Wiggins et al. 2006).

These cases of breeding far south of its usual breeding range demonstrate the Short-eared Owl's tendency to nomadism and opportunism (Stone et al. 1994, Figueroa-R. et al. 2009, Valdez-Gómez et al. 2009, Williford et al. 2011). The species' nesting is difficult to confirm because of its nocturnal habits, selection of remote areas, reluctance of adults to leave nests, and resorting to defensive behavior only when a threat is very near a nest or young (Wiggins et al. 2006). Nevertheless, in suitable habitat during the potential breeding season (mid-February-August), observers should be alert for Short-eared Owl breeding activity after ample rain elicits abundant growth of grasses and forbs and elevated densities of small mammals.

\section{ACKNOWLEDGMENTS}

We thank Lannois F. Neely for providing information regarding the initial Shorteared Owl observation in Roosevelt County and Patricia Mehlhop for preparing Figure 1. David A. Wiggins and Denver W. Holt assisted with aging the birds photographed in Roosevelt County. Matthew J. Baumann and David E. Quady provided helpful comments on the manuscript.

\section{LITERATURE CITED}

American Ornithologists' Union (AOU). 1998. Check-list of North American Birds, 7th ed. Allen Press, Lawrence, KS.

Avery, J. D., and Keller, G. S. 2006. Probable breeding of the Short-eared Owl (Asio flammeus) in eastern New Mexico. New Mexico Ornithol. Soc. Bull. 34:14-16.

Avery, J. D., and Keller, G. S. 2010. Short-eared Owl (Asio flammeus), in Raptors of New Mexico (J. E. Cartron, ed.), pp. 639-647. Univ. of New Mexico Press, Albuquerque.

Bent, A. C. 1938. Life histories of North American birds of prey, part 2. U.S. Natl. Mus. Bull. 170. Washington D.C.

Blaha, R. J., Hendricks, P., Nelson M. R., and Stewart, M. D. 1995. A Short-eared Owl nesting in Osage County, Oklahoma. Bull. Okla. Ornithol. Soc. 28:26-28.

Booms, T. L., Holroyd, G. L., Gahbauer, M. A., Trefry, H. E., Wiggins, D. A., Holt, D. W., Johnson, J. A., Lewis, S. B., Larson, M. D., Keyes, K. L., and Swengel, S. 2014. Assessing the status and conservation priorities of the Short-eared Owl in North America. J. Wildlife Mgmt. 78:1-7; doi 10.1002/jwmg.719.

Boyle, S. 1998. Short-eared Owl, in Colorado Breeding Bird Atlas (H. E. Kingery, ed.), pp. 226-227. Colo. Bird Atlas Partnership and Colo. Div. Wildlife, Denver.

Brown, J. H., and Heske, E. J. 1990. Temporal changes in a Chihuahuan Desert rodent community. Oikos 59:290-302; doi 10.2307/3545139.

Brown, J. H., and Zeng, Z. 1989. Comparative population ecology of eleven species of rodents in the Chihuahuan Desert. Ecology 70:1507-1525; doi $10.2307 / 1938209$. 
Clark, R. J. 1975. A field study of the Short-eared Owl, Asio flammeus (Pontoppidan), in North America. Wildlife Monogr. 47:1-67.

Clary, M. L., Bell, D. M., Edwards, C. W., Jolley, T. W., Knyazhnitskiy, O., LewisOritt, N., Mantooth, S. J., Peppers, L. L., Tiemann-Boege, I., Yancey, F. D. II, Howell, D. J., Locke, B. A., Baker, R. J., and Bradley, R. D. 1999. Checklist of mammals from twelve habitat types at Fort Bliss Military Base; 1997-1998. Occ. Pap. Mus. Tex. Tech. Univ. 192.

Dalquest, W. W., and Stangl, Jr., F. B. 1986. Post-Pleistocene mammals of the Apache Mountains, Culberson County, Texas, with comments on zoogeography of the Trans-Pecos Front Range. Mus. Tex. Tech. Univ. Occ. Pap. 104:1-35.

Enriquez-Rocha, P., Rangel-Salazar, J. L., and Holt, D. W. 1993. Presence and distribution of Mexican owls: A review. J. Raptor Res. 27:154-160.

Ernest, S. K., Brown, J. H., and Parmenter, R. R. 2000. Rodents, plants, and precipitation: Spatial and temporal dynamics of consumers and resources. Oikos 88:470-482; doi 10.1034/j.1600-0706.2000.880302.x.

Figueroa-R., R. A, Rau, J. R., Mayorga, S., Martínez, D. R., Corales-S., E. S., Mansilla, A., and Figueroa-M., R. 2009. Rodent prey of the Barn Owl Tyto alba and Short-eared Owl Asio flammeus during winter in agricultural lands in southern Chile. Wildlife Biol. 15:129-136; doi 10.2981/08-005.

Forbes, R. B. 1962. Notes on food of silky pocket mice. J. Mammal. 43:278-279; doi $10.2307 / 1377117$.

Garrett, K., and Dunn, J.. 1981. Birds of Southern California: Status and Distribution. Los Angeles Audubon Soc., Los Angeles.

Grinnell, J., and Miller, A. H. 1944. The distribution of the birds of California. Pac. Coast Avifauna 27.

Howell, S.N.G., and Webb, S. 1995. A Guide to the Birds of Mexico and Northern Central America. Oxford Univ. Press, New York.

Hubbard, J. P. 1978. Revised checklist of the birds of New Mexico. New Mexico Ornithol. Soc. Publ. 6.

Lightfoot, D. C., Davidson, A. D., Parker, D. G., Hernández, L., and Laundré, J.W. 2012. Bottom-up regulation of desert grassland and shrubland rodent communities: Implications of species-specific reproductive potentials. J. Mammal. 93:1017-1028; doi 10.1644/11-MAMM-A-391.1.

Ligon, J. S. 1961. New Mexico Birds and Where to Find Them. Univ. of New Mexico Press, Albuquerque.

Longland, W. S. 2007. Desert rodents reduce seedling recruitment of Salsola paulsenii. W. N. Am. Nat. 67:378-383; doi 10.3398/1527-0904(2007)67[378:DRR $\mathrm{SRO}] 2.0 . \mathrm{CO} ; 2$.

Mehlhop, P., Muldavin, E., Bennett, T., Wood, S., Yanoff, S., Douglas, N., and Radjy, S. 1996. Vegetation of Fort Bliss, Texas and New Mexico. Final report. Vol. II. Vegetation map. New Mexico Nat. Heritage Program, Albuquerque.

Nice, M. M. 1931. The Birds of Oklahoma, rev. ed. Publ. Univ. Okla. Biol. Surv. 3:1-224.

Pitelka, F.A., Tomich, P. Q., and Treichel, G. W. 1955. Ecological relations of jaegers and owls as lemming predators near Barrow, Alaska. Ecol. Monogr. 25:85-117; doi 10.2307/1943215.

Poulin, R.G., Wellicome, T. I., and Todd, L. D. 2001. Synchronous and delayed numerical responses of a predatory bird community to a vole outbreak on the Canadian prairies. J. Raptor Res. 35:288-295.

Roberson, D. 2008. Short-eared Owl (Asio flammeus), in California bird species of special concern: A ranked assessment of species, subspecies, and distinct populations of birds of immediate conservation concern in California. Studies of Western Birds 1. (W. D. Shuford and T. Gardali, eds.), pp. 242-248. W. Field Ornithol., Camarillo, California, and Calif. Dept. Fish and Game, Sacramento. 
Schmidly, D. J. 2004. The Mammals of Texas, rev. ed. Univ. of Tex. Press, Austin.

Stamm, A. L., and Clay, K. W. 1989. First breeding record of the Short-eared Owl in Kentucky. Kentucky Warbler 65:75-76.

Stone, E., Smith, J., and Thornton, P. 1994. Seasonal variation and diet selection from pellet remains of Short-eared Owls (Asio flammeus) in Wyoming. Great Basin Nat. 54:1919-192.

Thibault, K. M., and Brown, J. H. 2008. Impact of an extreme climatic event on community assembly. Proc. Nat. Acad. Sci. 105:3410-3415; doi 10.1073/ pnas. 0712282105.

Valdez-Gómez, H. E., Holroyd, G. L., Trefry, H. E., and Contreras-Balderas, A. J. 2009. Do the winter diets of sympatric Burrowing Owl and Short-eared Owl overlap in west-central Mexico? in Proceedings of the Fourth International Partners in Flight Conference (T. D. Rich, C. Arizmendi, D. W. Demarest, and C. Thompson, eds.), pp. 96-101. Partners in Flight. McAllen, TX.

Wiggins, D. 2004. Short-eared Owl (Asio flammeus): A technical conservation assessment. USDA Forest Service, Rocky Mountain Region.

Wiggins, D. A., Holt, D. W., and Leasure, S. M. 2006. Short-eared Owl (Asio flammeus), in The Birds of North America Online (A. Poole and F. Gill, eds.), no. 62. Cornell Lab. Ornithol., Ithaca, NY; doi 10.2173/bna.62.

Williford, D., Woodin, M. C., and Skoruppa, M. K. 2011. The winter diet of Shorteared Owls in sub-tropical Texas: Do southern diets provide evidence of opportunism? J. Raptor. Res. 45:63-70; doi 10.3356/JRR-10-40.1.

Wilson, P. W. 1995. Short-eared Owls nest unsuccessfully in northeast Oklahoma. Bull. Okla. Ornithol. Soc. 28:24-26.

Accepted 22 January 2016 